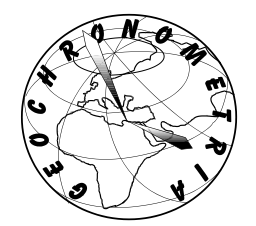

\title{
ERRATUM
}

\section{HUMAN-PLANTED ALDER TREES AS A PROTECTION AGAINST DEBRIS FLOWS (A DENDROCHRONOLOGICAL STUDY FROM THE MOXI BASIN, SOUTHWESTERN CHINA)}

\author{
IRENEUSZ MALIK ${ }^{1,2}$, YONGBO TIE ${ }^{2}$, PIOTR OWCZAREK ${ }^{3,2}$, MALGORZATA WISTUBA ${ }^{1}$, \\ WOJCIECH PILORZ ${ }^{1}$ and BEATA WOSKOWICZ-ŚLEZZAK ${ }^{1}$ \\ ${ }^{I}$ Department of Reconstructing Environmental Change, Faculty of Earth Sciences, University of Silesia, \\ ul. Będzińska 60, 41-200 Sosnowiec, Poland \\ ${ }^{2}$ Chengdu Centre of China Geological Survey, State Key Laboratory of Geohazard Prevention and Geoenvironment Protection, \\ Chengdu University of Technology, No. 2 of N-3-Section of First Ring Road, Chengdu, China \\ ${ }^{3}$ Institute of Geography and Regional Development, University of Wroctaw, \\ pl. Uniwersytecki 1, 50-137 Wroctaw, Poland
}

Erratum to:

GEOCHRONOMETRIA 40(3) 2013: 208-216, HUMAN-PLANTED ALDER TREES AS A PROTECTION AGAINST DEBRIS FLOWS (A DENDROCHRONOLOGICAL STUDY FROM THE MOXI BASIN, SOUTHWESTERN CHINA)

DOI 10.2478/s13386-013-0113-X

The online version of the original article can be found at: http://dx.doi.org/10.2478/s13386-013-0113-x

The original version of this article unfortunately contained wrong Fig. 10. Opposite, the correct version of Fig. 10 is given.
Corresponding author: I. Malik e-mail: irekgeo@wp.pl
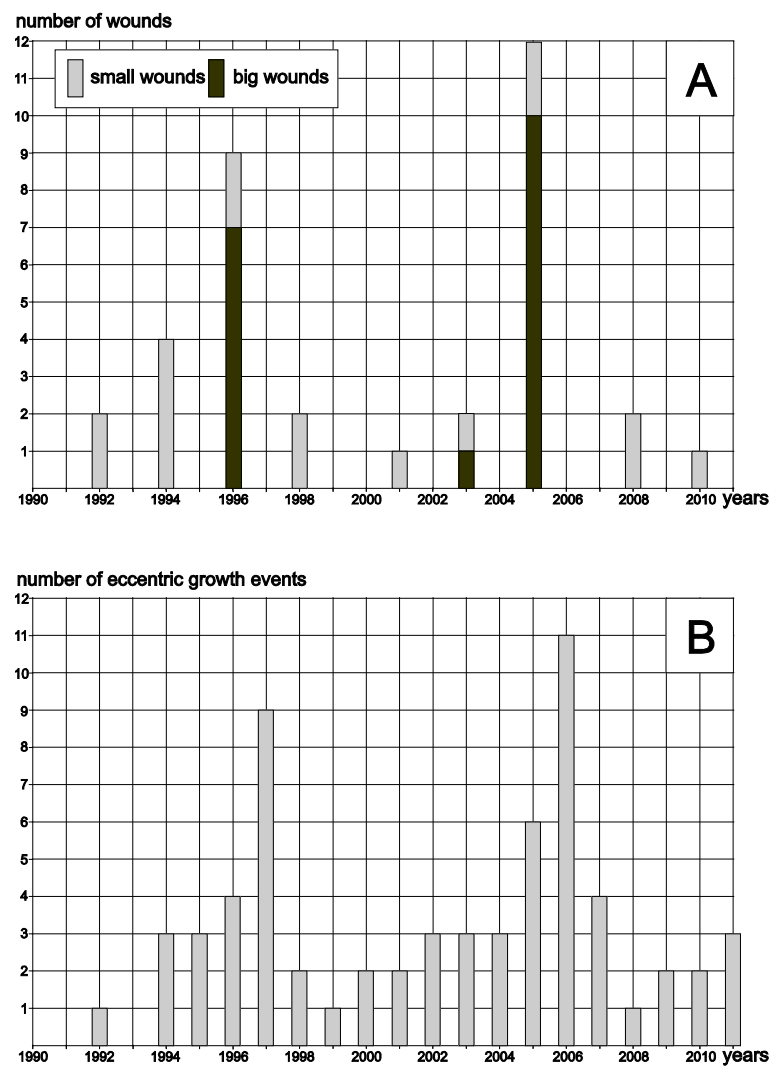

Fig. 10. The number of debris flow events recorded by tree-ring analyses, (A) - results of the dating of wounded alder stems, (B) - results of the dating using eccentric growth.

Apringer 